\title{
Systemically Applied Insecticides for Treatment of Erythrina Gall Wasp, Quadrastichus erythrinae Kim (Hymenoptera: Eulophidae)
}

\author{
Joseph J. Doccola, Sheri L. Smith, Brian L. Strom, Arthur C. Medeiros, and Erica von Allmen
}

\begin{abstract}
The erythrina gall wasp (EGW), believed native to Africa, is a recently described species and now serious invasive pest of Erythrina (coral trees) in tropical and subtropical locales. Erythrina are favored ornamental and landscape trees, as well as native members of threatened ecosystems. The EGW is a tiny, highly mobile, highly invasive wasp that deforms (galls) host trees causing severe defoliation and tree death. The first detection of EGW in the United States was in O'ahu, Hawai' $\mathrm{i}$ in April 2005. It quickly spread through the Hawai ian island chain (U.S.) killing ornamental and native Erythrina in as little as two years. At risk are endemic populations of Erythrina as well as ornamental landscape species in the same genus, the latter of which have already been killed and removed from O'ahu at a cost of more than USD \$1 million. Because EGW are so small and spread so quickly, host injury is usually detected before adult wasps are observed, making prophylactic treatments less likely than therapeutic ones. This study evaluates two stem-injected insecticides, imidacloprid (IMA-jet $\AA$ ) and emamectin benzoate, delivered through Arborjet Tree I.V.® equipment, for their ability to affect E. sandwicensis (wiliwili) canopy demise under severe EGW exposure. IMA-jet, applied at a rate of $0.16 \mathrm{~g} \mathrm{AI} / \mathrm{cm}$ basal diameter $(0.4 \mathrm{~g} \mathrm{AI} / \mathrm{in}$. dia.), was the only effective treatment for maintaining canopy condition of wiliwili trees. Emamectin benzoate, applied at a rate of $\sim 0.1 \mathrm{~g} \mathrm{AI} / \mathrm{cm}$ basal diameter $(\sim 0.25 \mathrm{~g} \mathrm{AI} / \mathrm{in}$. dia.), was not effective in this application, although it was intermediate in effect between IMA-jet and untreated trees. The relatively high concentrations of imidacloprid in leaves, and its durability for at least 13 months in native wiliwili growing on a natural, dryland site, suggest that treatment applications against EGW can impact canopy recovery even under suboptimal site and tree conditions.

Key Words: Coral Trees; Emamectin Benzoate; Erythrina sandwicensis; Imidacloprid; Tree Injection; Wiliwili.
\end{abstract}

The erythrina gall wasp (EGW), Quadrastichus erythrinae Kim (Hymenoptera: Eulophidae), believed native to Africa, was first described in 2004 from specimens collected in Taiwan (Kim et al. 2004). The gall wasp is currently a serious pest of ornamental and native Erythrina (coral trees) in multiple distant locales and is predicted to spread to five continents, including the entire tropical and subtropical world (Li et al. 2006). In Hawai' $\mathrm{i}$ (U.S.) and elsewhere, Erythrina have been planted extensively at airports, parks, private residences, and farms. They are also commonly used for windbreaks and soil and water conservation, and the Hawai ian endemic species, Erythrina sandwicensis O. Deg. (Fabaceae) is a keystone species of low-elevation dryland forests as well as an important Hawai ian cultural and ethnobotanical resource.

Erythrina sandwicensis, known locally as wiliwili, can grow 9-13 m (30-45 ft) tall, with a broad, spreading habit (Wagner et al. 1990). Leaves are alternate, compound, $13-30 \mathrm{~cm}(5.1-12$ in) long, with a long slender leafstalk. The three leaflets are shortstalked with the most distal being larger than the other two. Leaflets are 4-10 cm (1.6-3.9 in) long and 6-15 cm (2.3-5.9 in) wide (Wagner et al. 1990). Wiliwili grows in dry forests on leeward slopes of all the main islands to an elevation of $600 \mathrm{~m}$ (2000 ft) (Powell and Nakao 1992). Rhizobial and endomycorrhizal root associates fix nitrogen and solubolize phosphorous, important adaptations for survival in its native habitat (Powell and Nakao 1992). Outer bark is thin and stems are photosynthetically active. Wiliwili is dry-season deciduous; on the island of
Maui, Hawai'i, leaves are most frequently present from November through April depending on rainfall (Powell \& Nakao 1992).

Erythrina species are the only known hosts for EGW. The genus includes about 115 species native to tropical and subtropical regions (Neill 1993); at least 59 appear to be hosts for EGW (Messing et al. 2009; W. Fulton, National Tropical Botanical Garden, pers. comm.). In botanical gardens in Hawai' $i$, the most severe injury has been observed on species of non African origin, supporting the putative African origin of EGW (Messing et al. 2009). Erythrina's showy flowers make them popular ornamentals that are cultivated in landscapes and horticultural gardens in locations such as southern California, Florida and Hawai'i (Figure 1A, Figure 1B). The largest collection of Erythrina species on the continental United States is found at the San Diego Zoo, where 53 species are currently growing (San Diego Zoo 2008). The degree of worldwide susceptibility to EGW is uncertain because Erythrina species differ in their host-quality for the wasp and many species have not yet been exposed. Indian coral tree, Erythrina variegata (L.) Merr., native to India and Malaysia, is used as an ornamental and street tree in warmer regions worldwide and is a favorite host of EGW. Two forms of $E$. variegata, a tall, columnar, windbreak form and a more spreading, ornamental form, were nearby to initial EGW detection sites in Hawai'i and likely facilitated its spread into native forests.

The EGW was first detected in the United States on O'ahu, Hawai' 1 in April 2005 (Heu et. al. 2006) and spread to the other Hawai ian 


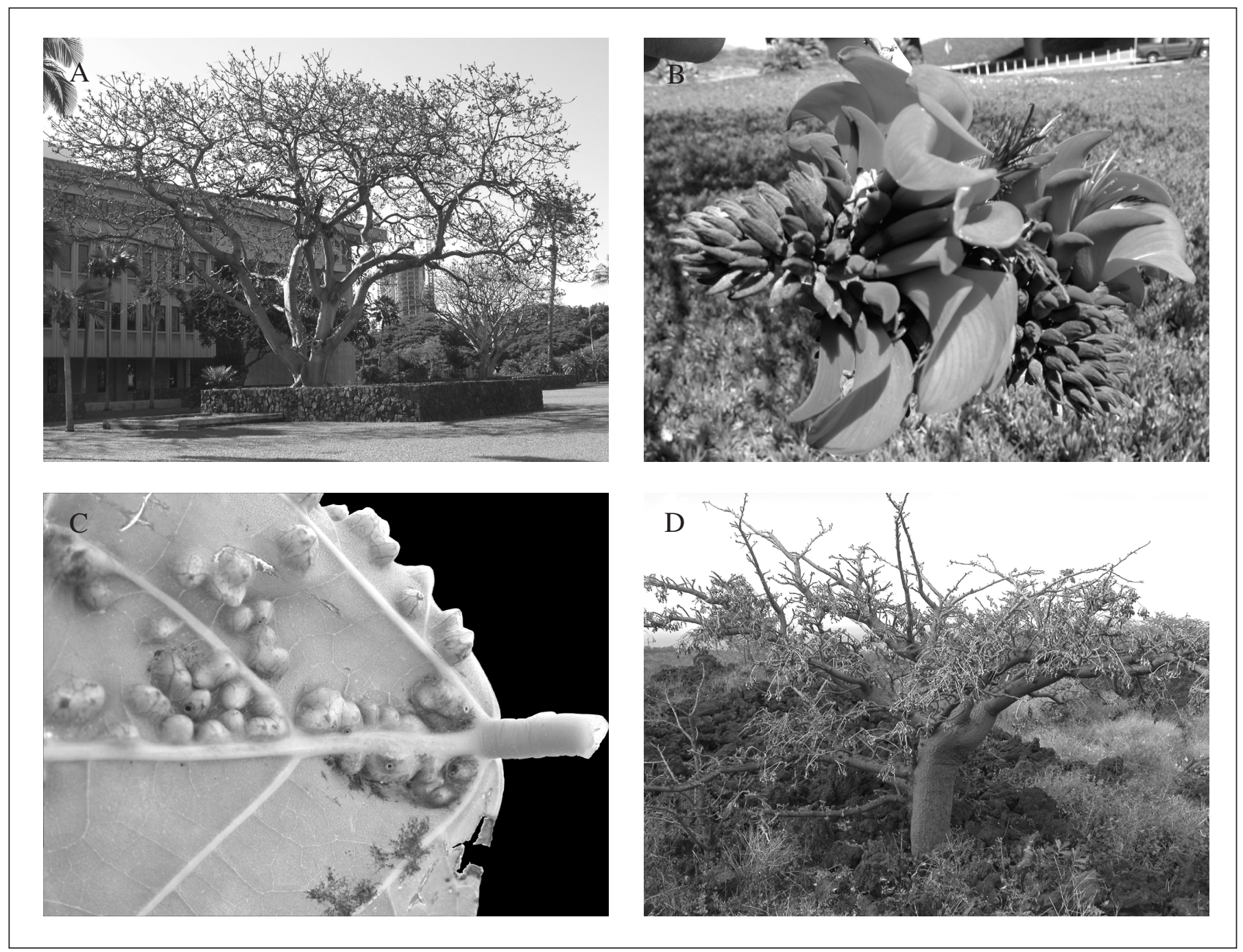

Figure 1. Erythrina trees are common, frequently high-value ornamentals (A), planted for their showy flowers (B). The erythrina gall wasp prefers to oviposit in succulent host tissues, causing injury that ranges from simple leaf galls (C) to swelling to branch dieback. Cumulative effects cause tree death in as little as one to two years. Recently dead Erythrina sandwicensis in its native habitat, Pu'u-o-kali, Maui (D).

Islands in less than six months. Erythrina variegata have already suffered widespread and nearly complete mortality (believed $>95 \%$ ) in Hawai'i. On O'ahu alone the cost of removing dead E. variegata has exceeded USD $\$ 1$ million. Relative to E. variegata, E. sandwicensis is less severely infested and injured from EGW (Messing et al. 2009). Nevertheless, tree injury and mortality occur in the native wiliwili (Figure 1C, Figure 1D); current estimates place mortality at approximately $10 \%$ (Medeiros, pers. observation). Widespread mortality of E. variegata has resulted in wiliwili being the major host resource that remains for EGW in Hawai'i; a situation with uncertain consequences. The survival of wiliwili in Hawai'ian dryland forests has been questioned since EGW's introduction and in response, a seed-banking effort on Maui netted $>90,000$ seed from 70 populations (Medeiros, unpublished). Human activities have removed $>90 \%$ of dryland forests in Hawai $i$, and remnants are considered highly threatened (Medeiros et al. 1986). The introduction of EGW has added even more pressure to this dwindling resource.

The wasp was detected in south Florida in October 2006 (Wiley and Skelley 2006), further demonstrating its invasive capabilities and confirming the expectation that arrival to the mainland of the
United States was imminent. It has not yet been detected in nonnative ornamental populations of Erythrina along the southern California coast or in the native species in Arizona and New Mexico (E. flabelliformis Kearney), but introduction and establishment are considered likely. Erythrina flabelliformis is susceptible to EGW in common garden trials in Hawai $i$ and, depending on susceptibility of untested species, native and nonnative Erythrina throughout North America and Mexico may be threatened (Smith et al. 2007).

EGW adults are very small, $1 \mathrm{~mm}$ in length; consequently, host injury (galling and defoliation) (Figure 1C) is generally detected before wasps are observed (Smith and Strom 2007). Adult females produce hundreds of eggs, preferring to oviposit in young, succulent tissues, primarily leaves and petioles (Heu et al. 2006). Oviposition to adult emergence requires about 21 days (Heu et al. 2006), so infestations develop rapidly and easily escape early detection. Eradication (e.g., via pruning or tree removal) has not been successful, and biological control agents are still being evaluated and developed. Early detection offers tree and landscape managers the widest array of options with systemic insecticides offering a hopeful, interim treatment possibility. 
Methods for effective prophylaxis and rapid response are crucial for limiting EGW-caused Erythrina mortality. Short-term strategies center around systemic insecticides and longer-term strategies on traditional biological control (Heu et al. 2006, Xu et al. 2008). Insecticides applied by tree injection provide a number of benefits which may include compact equipment for use in remote areas, little or no water required for application, less volume of active ingredient needed for treatment and potentially less environmental exposure compared to soil or foliar treatments, systemic movement of chemistry into the targeted tissues, relatively greater residual activity, and less frequent applications (compared to canopy sprays). Imidacloprid, applied as a systemic, caused significant mortality of EGW in Hawai'i (Xu et al. 2006). Xu et al. (2006) found that concentrations of imidacloprid in E. sandwicensis leaf tissue were correlated inversely with host injury and wasp emergence; as tissue concentrations reached 8 ppm, wasp emergence from galled tissues dropped by $80 \%$. However, this level of imidacloprid concentration was obtained only in trees located in an irrigated resort landscape. Concentrations of imidacloprid using either the Sidewinder ${ }^{\circledR}$ (Sidewinder Pty Ltd, Noosaville, Australia) or Wedgle ${ }^{\circledR}$ (ArborSystems, LLC, Omaha, NE, U.S.) injection systems on native wiliwili in dryland forests did not exceed 5 ppm after 4-5 months. Therefore, injection systems and/or formulations that produce higher tissue concentrations of imidacloprid are needed to improve protection options for trees in harsher environments. Emamectin benzoate (Syngenta Crop Protection Inc., Greensboro, NC, U.S.) has not been evaluated for efficacy in this system, but applications in other pest control situations suggest that it can provide longer residual activity than imidacloprid (Grosman et al. 2002; Doccola et al. unpublished). Imidacloprid is a widely used neonicotinoid and emamectin benzoate is a semi-synthesized avermectin compound with broadspectrum activity against insects. This study evaluated imidacloprid and emamectin benzoate for their effectiveness in reducing host injury caused by EGW in a native wiliwili dryland forest. Both active ingredient (AI) formulations were injected with Tree I.V.® equipment (Arborjet, Inc., Woburn, MA, U.S.); imidacloprid as IMA-jet ${ }^{\circledR}$ (Arborjet, Inc.) and emamectin benzoate as a formulation that has evolved to TREE-äge ${ }^{\circledR}$ (Syngenta Crop Protection, Inc.). IMA-jet is registered for use in the United States and TREE-äge has been submitted for registration to the United States Environmental Protection Agency. The study authors believe that environmental conditions at the site, along with the natural growth form of E. sandiwicensis and pre-existing canopy injury caused by EGW, combined to make results of this study conservative relative to applications implemented under more typical ornamental conditions, especially those with supplemental watering.

\section{METHODS}

Sixty E. sandwicensis trees (20 per treatment) were selected for this experiment with consideration of their canopy health (average for the forest), diameter (avoiding outliers), location away from other experiments within the fenced exclosure, and nearness to equipment access at the site in Pu'u-o-kali, Maui, Hawai' 1 , USA $\left(20^{\circ} 44^{\prime} 05.78^{\prime}\right.$ 'N $\left.156^{\circ} 24^{\prime} 11.57^{\prime \prime} \mathrm{W}\right)$. Pu'u-o-kali is on leeward southwestern Maui [210 m (689 ft) elevation], near Kihei, and experiences hot and dry weather with only seasonal rainfall (375-500 $\mathrm{mm}$ per year; $15-20 \mathrm{in} / \mathrm{yr}$ ). Trees were estimated to be up to several hundred years old at the time of treatment and ranged from 23 to $74 \mathrm{~cm}(\bar{x}=41.7 \mathrm{~cm})(9.6$ to 29.6 in; $\bar{x}=16.4$ in) in basal diameter (Table 1$)$. Treatments were implemented in January 2007 (see below), about 1.5 years after initial detection of EGW on Maui. Thus, trees were infested and had suffered significant (but unquantified) canopy injury prior to treatment. Pre- and post-treatment canopy condition and injury were evaluated using three measures: canopy foliage density, the ratio of galled to total leaf area, and branch tip dieback. Canopy foliage density was estimated for each tree using a spherical densiometer (Model C, Robert E. Lemmon, Bartlesville, OK, U.S.; Lemmon 1956). Densiometer measurements were taken at the four cardinal directions with the user's back to the tree bole. Total and galled leaf areas were estimated with a square centimeter grid from branch tips at the outer edge of the lower canopy. One branch tip was chosen at each of four randomly selected compass points. For densiometer and galled to total leaf area measurements, tree means were produced to provide a single value per tree for analysis. Branch tip dieback was estimated by visually examining the entire crown of each tree to categorize percent dieback as zero or in $25 \%$ increments (five categories). All measurements were recorded at time of treatment ( 0 months) and 13 months thereafter. Foliage was sampled for determination of insecticide residues at 0 months, 35 days and 13 months.

Study trees received one of three randomly assigned AI treatments: emamectin benzoate (Avermectin $\mathrm{B}_{1}$, 4"-deoxy4"-(methylamino)-, (4"R)-, benzoate (salt), formulated at 4.21 $\mathrm{g} / 100 \mathrm{~g}$ concentration); imidacloprid $\{1$-[(6-chloro-3-pyridinyl) methyl]-N-nitro-2-imidazolidinime formulated as IMA-jet at 5 $\mathrm{g} / 100 \mathrm{~g}$ concentration $\}$; or none (untreated control trees). Insecticide application methods and rates were determined from existing (IMA-jet) or submitted (TREE-äge) insecticide product labels. Dosage rates for the emamectin benzoate formulation were $1.6-2.4 \mathrm{ml} / \mathrm{cm}$ diameter (4-6 ml/dia. in) and $1.6,3.2$ or 4.8 $\mathrm{ml} / \mathrm{cm}$ diameter $(4,8$ or $12 \mathrm{ml} /$ in diameter $)$ for trees $<30 \mathrm{~cm}$, $30-58 \mathrm{~cm}$, and $>58 \mathrm{~cm}(<12,12-23$, and $>23$ in diameter $)$ respectively, for IMA-jet. In applications against pests with chew-

Table 1. Summary of mean treatment dosages, costs, uptake times and changes in galled to total leaf area and insecticide residues recovered from leaf tissues in Erythrina sandwicensis at Pu'u-o-kali, Maui, HI, U.S.

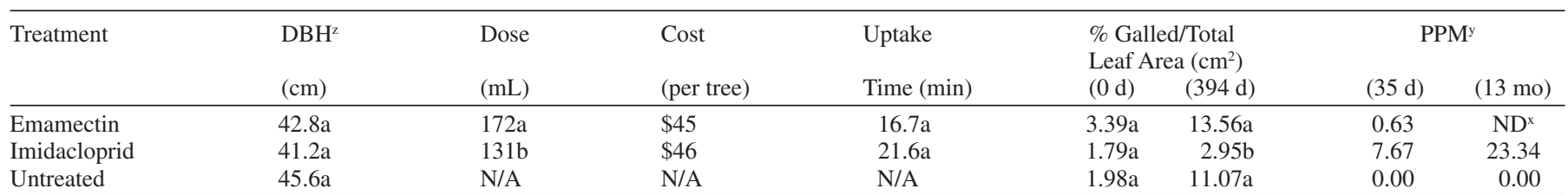

${ }^{\mathrm{z}}$ Means followed by the same letter in a column are not statistically different, $\mathrm{n}=19-20$ trees per treatment.

${ }^{y}$ Values are uncorrected for percent efficiency of chemical extraction.

${ }^{x}$ Minimum detectable limit $=0.01 \mathrm{PPM}$ 
ing mouthparts (e.g., emerald ash borer, Smitley et al. unpublished), emamectin benzoate demonstrated greater activity $(\sim 2 \mathrm{x})$ to imidacloprid. In this design, the emamectin benzoate treated trees received $\sim 0.5 \mathrm{x}$ the grams active ingredient compared to the imidacloprid treated trees. Following label instructions, the emamectin benzoate formulation was mixed with an equal volume of water at application, while IMA-jet was applied as formulated.

Basal injections into the stem or root flare (Figure 2) occurred on January 29 or 30, 2007 using the Tree I.V. system. The Tree I.V. has a $650 \mathrm{ml}$ liquid capacity that is pressurized to $172-241$ $\mathrm{kPa}(25-35 \mathrm{PSI})$ at the time of application and distributed among 4 to 16 needle assemblies based on tree diameter. A $9 \mathrm{~mm} \mathrm{(3/8} \mathrm{in)}$ diameter bit was used to drill into the sapwood to a depth of $\sim 15$ $\mathrm{mm}(5 / 8 \mathrm{in}$.) at a right angle to the stem. Once the hole was drilled, an Arborplug was inserted to create the injection site. The Arborplug is designed to prevent backflow of insecticide formulation from the tree and accepts a $1.6 \mathrm{~mm}$ diameter injector needle; the Arborplug remains in the tree following treatment. Application sites were located every $15-20 \mathrm{~cm}(6-8$ in) of tree circumference. The duration of time necessary for the bottle and lines to empty was considered uptake time and was recorded for each tree. Mean uptake times for IMA-jet and emamectin benzoate formulations were compared by t-test to determine significant differences.

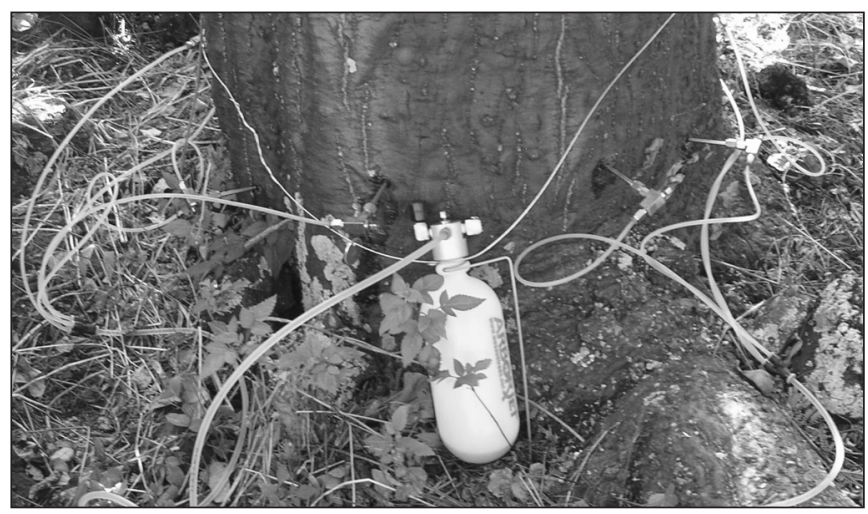

Figure 2. Native wiliwili on Maui were stem-injected using Arborjet Tree I.V. equipment.

Insecticide residues were determined from foliage samples collected from each tree at the four cardinal directions at time of treatment, and $35 \mathrm{~d}$ and 13 months thereafter (Table 1). Foliage samples were taken from the outer edge of the lower canopy. Generally two samples were analyzed and their mean reported, but when sample weights were too little they were combined as needed to obtain at least $1 \mathrm{~g}$ dry weight. Imidacloprid residues were determined by high-pressure liquid chromatography (HPLC) following freeze-drying, grinding and extraction with acetonitrile. Leaf tissues for emamectin benzoate residue analyses were prepared similarly and followed a simplified version of the procedures described by Takai et al. (2003); residues were determined using fluorescence HPLC. Values are reported in parts per million (PPM) and are uncorrected for the proportion of chemical recovered from samples, which was $\sim 0.50$. The minimum detection limit for emamectin benzoate was 0.01 PPM.

As previously described, treatment effects were evaluated using canopy foliage density, the ratio of galled to total leaf area and branch tip dieback as response variables. For continuous response variables, one-way analysis of variance (ANOVA) was used on pre-treatment data to ensure that treated tree populations were not different in the responses measured. Treatment effects were evaluated by subjecting mean within-tree differences at 0 and 13 months to one-way ANOVA (e.g., Mathews et al. 1990). Mean separations were done using Tukey's HSD. In addition, paired t-tests were used to evaluate changes in canopy density for each treatment separately; these data were arcsin transformed prior to analysis to better meet statistical assumptions. For categorical response variables, Fisher's Exact Test was used to evaluate treatment effects; separate analyses were conducted for data gathered at time of treatment and 13 months. A paucity of trees in the two categories of least injury ( 0 and $1 \%-25 \%)$ led to analysis on only three categories: $<50 \%$, $50 \%-75 \%$ and $76 \%-100 \%$. Uptake times for the two insecticide formulations were compared using a t-test. Statistical analyses were conducted using MINITAB (Version 15, Minitab, Inc. State College, PA, U.S.) or Stata (Version 10, StataCorp, College Station, TX, U.S.) with significance accepted when $P<0.05$.

\section{RESULTS}

Mean formulation dosages and uptake times were $131 \mathrm{ml}$ in 21.6 minutes for IMA-jet and $172 \mathrm{ml}$ in 16.7 minutes for the diluted emamectin benzoate formulation. Dosages of active ingredients follow as $6.6 \mathrm{~g}$ imidacloprid and $3.4 \mathrm{~g}$ emamectin benzoate. Despite total injected volumes differing (as per label instructions), uptake times were not significantly different between insecticide treatments $(P=0.184$, t-test $)$; emamectin benzoate infused into tissues at a higher rate (mean of $13.6 \mathrm{ml} / \mathrm{min}$ ) compared to IMA-jet (mean of $8.8 \mathrm{ml} / \mathrm{min}$ ) though this was not statistically significant $(P=0.065)$. The difference in flow rates is likely a function of formulation dilution rather than canopy transpiration (McWain and Gregory 1973). Although transpiration was not measured, leaf area reflects surface transpiration area (Santiago et al. 1999) and pretreatment canopies were similar among treatments (see below). Tree canopy evaluations (foliage density, galled to total leaf area, branch tip death) did not differ among treatments at treatment time $(P>0.05$; Table 1).

Canopy foliage density at time of treatment averaged $26.3 \%$ (range from 9.14\%-49.92\%) for all study trees. Both untreated $(\bar{x}=25.8 \pm 2.3 \%$ versus $\bar{x}=15.0 \pm 1.6 \%)$ and emamectin benzoate treated $(\bar{x}=27.7 \pm 2.9 \%$ versus $\bar{x}=19.9 \pm 2.1 \%$ ) trees lost significant canopy density between sample periods at 0 and 13 months $(P<0.05$; Figure 3A). However, injection with imidacloprid stabilized loss of canopy; there was no significant difference in canopy foliage density at time of treatment $(\bar{x}=25.3 \pm 2.8 \%)$ and 13 months $(\bar{x}=24.9 \pm 3.4 \%$; $P=0.77)$. Analysis on differences in canopy density revealed that imidacloprid treatment $(\bar{x}=0.3 \%$ loss $)$ was best, but not significantly better than emamectin benzoate $(\bar{x}=7.8 \%)$, which was not significantly better than no treatment $(\bar{x}=11.6 \%)$.

Ratio of galled to total leaf area provided additional evidence for the superiority of IMA-jet in this application. Trees assigned different treatments did not differ in pre-treatment galled to total leaf areas (Table 1). All treatments showed a numerical increase in galled to total leaf area at 13 months relative to pretreatment, demonstrating the pressures realized from EGW at the study site. However, canopy changes in the imidacloprid treatments alone were insignificant. Untreated trees showed a 


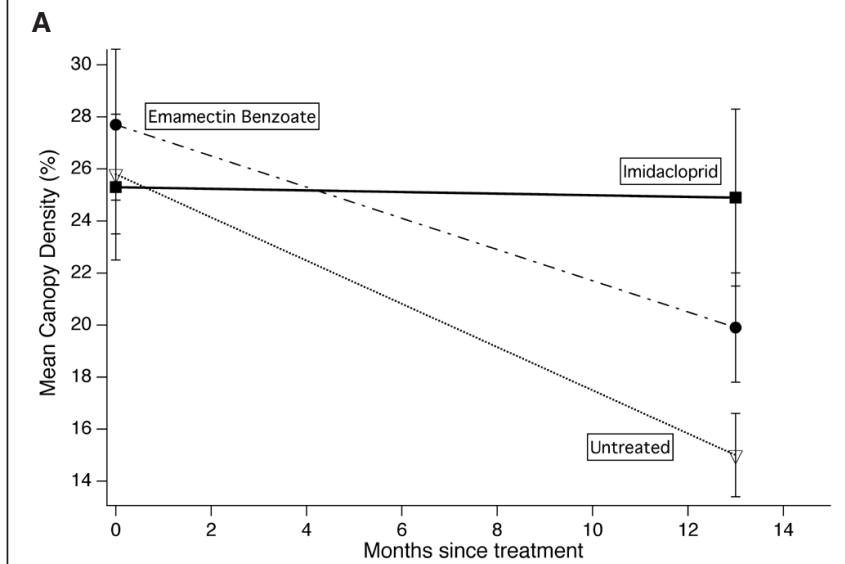

B

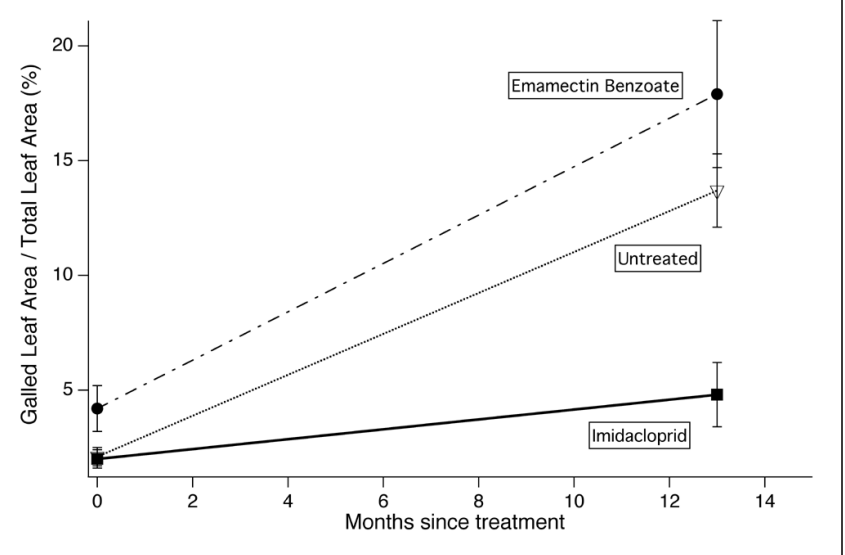

Figure 3. (A) Percentage canopy density of wiliwili growing at Pu'u-o-kali, Maui, $\mathrm{HI}$ at time of treatment and 13 months posttreatment. Both untreated ( $\bar{x}=25.8 \pm 2.3 \%$ vs $\bar{x}=15.0 \pm 1.6 \%)$ and emamectin benzoate treated ( $\bar{x}=27.7 \pm 2.9 \%$ vs $\bar{x}=19.9 \pm 2.1 \%$ ) trees lost significant canopy density between sample periods at 0 and 13 months $(P<0.05)$. However, injection with imidacloprid stabilized loss of canopy such that there was no significant difference in canopy foliage density at time of treatment $(\bar{x}=$ $25.3 \pm 2.8 \%$ ) and 13 months $(\bar{x}=24.9 \pm 3.4 \% ; \mathrm{P}=0.77)$. There vure no differences in mean canopy density pretreatment. (B) Percentage of galled leaf area/total leaf area in wiliwili growing at Pu'u-okali, Maui, $\mathrm{HI}$ at time of treatment and 13 months post-treatment. Untreated trees showed a mean galled to total leaf area increase from $2.0 \%$ at treatment to $11.1 \%$ at 13 months $(P=0)$. Trees treated with emamectin benzoate showed an increase from $3.4 \%$ to $13.6 \%(P=0)$, while those treated with imidacloprid increased only slightly from $1.8 \%$ to $2.9 \%(P=0.188)$.

mean galled to total leaf area increase from $2.0 \%$ at treatment to $11.1 \%$ at 13 months $(P=0)$. Trees treated with emamectin benzoate showed an increase from $3.4 \%-13.6 \%(P=0)$, while those treated with imidacloprid increased only slightly from $1.8 \%-2.9 \%(P=0.188$; Figure 3B $)$. Comparing differences among treatments demonstrated that IMA-jet was the most effective treatment for limiting galled to total leaf area $(P<0.05$, Tukey's HSD). Emamectin benzoate and untreated treatments were statistically indistinguishable $(P>0.05$, Tukey's HSD).

Before treatment, branch tip dieback also did not differ among trees in different treatment categories $(P=0.47$; Fisher's Exact Test; Figure 4A). After 13 months, there were significantly

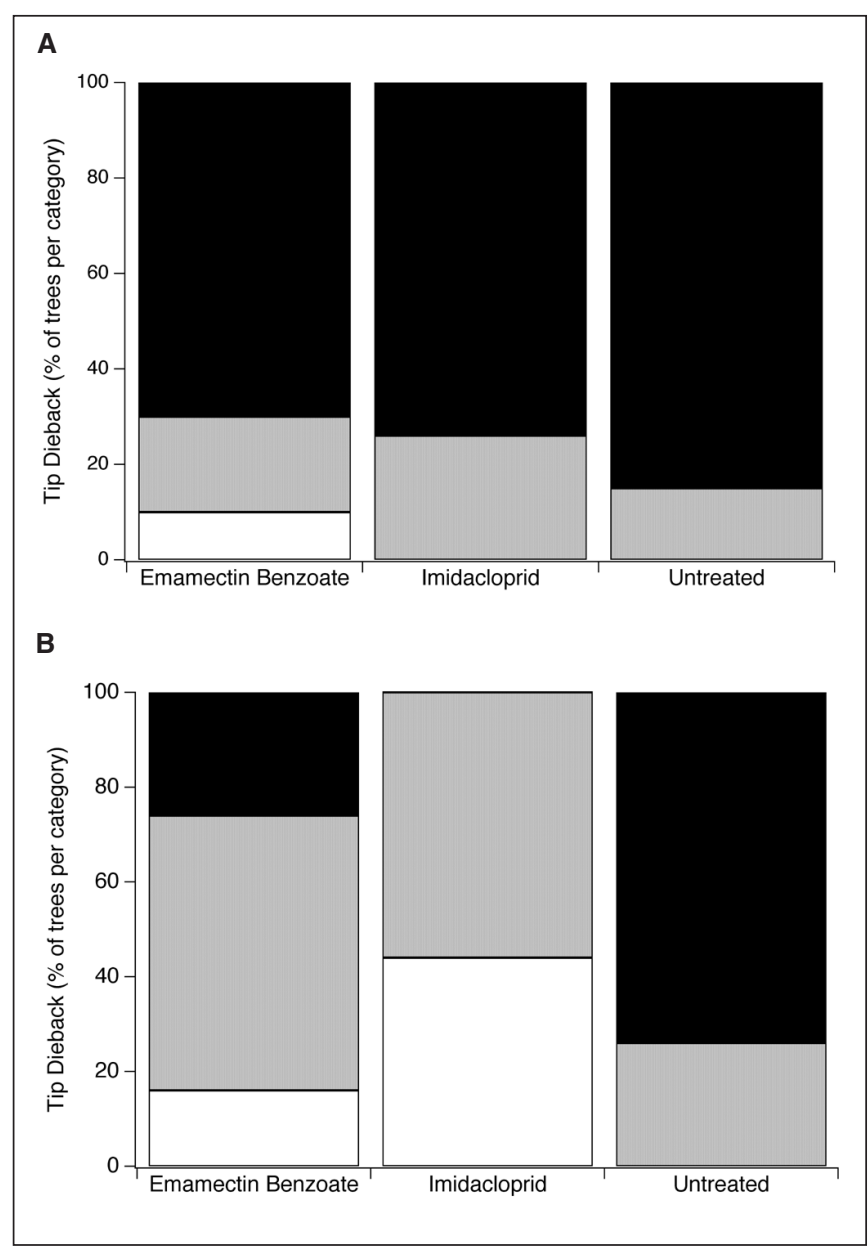

Figure 4. Percentage of trees in each of three tip dieback categories at time of treatment $(A)$ and 13 months afterward (B). Darker shading indicates more severe tip dieback. White indicates the percentage of trees with $<50 \%$ tip dieback; gray indicates the percentage of trees with $\mathbf{5 1} \%-\mathbf{7 5 \%}$ tip dieback and black indicates the percentage of tees with $76 \%-100 \%$ tip dieback. There were no statistically significant differences (Fisher's Exact Test; $\boldsymbol{P}>0.05$ ) among trees in different treatments at the time of treatment, but all treatments were different at 13 months (Fisher's Exact Test; $\boldsymbol{P}<0.05$ ) with IMA-jet being least injured, emamectin benzoate intermediate and untreated being most severely injured.

more trees in less-injured categories among those treated with imidacloprid than either emamectin benzoate $(P=0.03)$ or untreated $(P=0)$. Trees treated with emamectin benzoate did fare significantly better than untreated trees $(P=0.006)$, showing again the intermediate effect of this treatment (Figure 4B).

Variability of insecticide residues was observed in sampled leaves over time (Table 1). Mean residue concentrations for imidacloprid increased from 7.7-23.3 ppm at $35 \mathrm{~d}$ and 13 months, respectively. The study period of 13 months encompassed one leaf drop and refoliation event for the summer (dry season) deciduous E. sandwicensis, so higher values of imidacloprid were observed after the emergence of new leaves. Emamectin benzoate was applied at half the AI concentration of imidacloprid and had significantly lower residues. Mean residues observed at $35 \mathrm{~d}$ were $0.63 \mathrm{ppm}$ (range $0.05-2.49 \mathrm{ppm}$ ) and no residues were detected at 13 months. 


\section{DISCUSSION}

Despite severe EGW pressure at the treatment site, native wiliwili trees treated with trunk-injected imidacloprid maintained their pretreatment canopy conditions over the 13 months of this study; untreated trees or those treated with emamectin benzoate experienced significant canopy loss. Previous studies have demonstrated the toxicity of systemic imidacloprid to EGW (Xu et al. 2006; Xu et al. 2008); however, their goals were to evaluate many treatment, formulation and site combinations in a short period of time. The present study focused on evaluating imidacloprid and emamectin benzoate applied with one delivery system to native Hawai ian wiliwili in natural, dryland conditions. The site, climatic and tree conditions were not ideal for insecticide injection and subsequent distribution in the plant, and should provide a conservative estimate of the recovery possible following injection. Xu et al. (2006) report that an imidacloprid concentration of about $8 \mathrm{ppm}$ in Erythrina leaves reduces EGW adult emergence by $80 \%$. The authors use this value as the threshold for an effective concentration level in the study. Observed concentrations of imidaclopid in leaves at $35 \mathrm{~d}(7.7 \mathrm{ppm})$ and 13 months (23.3 ppm) correspond well with the $80 \%$ reduction in wasp emergence and exceed by 2-12 times the concentrations previously reported for dryland forest $E$. sandwicensis injected with a different system (Sidewinder and Imicide $®$; Xu et al. 2006).

Application method and formulation play important roles in the movement of systemics into target plant tissues. Various imidacloprid formulations and application techniques were evaluated by Xu et al. (2008) on the tall columnar form of E. variegata near Hilo, Hawaíi (3050-4575 mm rainfall per year) (120-180 in). Treatments included Merit $2 \circledR$ applied as a soil drench, Merit 200 SL® (Bayer CropScience) and IMA-jet stem-injection using the Arborjet Tree I.V., Pointer ${ }^{\circledR}$ formulation injected with the Wedgle system (ArborSystems, LLC.), and Imicide dispensed through Mauget capsules (JJ Mauget Co, Arcadia, CA, U.S.). Mean concentrations of imidacloprid in leaves from four replicate trees exceeded 8 ppm by 21 days post-injection, and remained above this level in trees treated with either IMA-jet or Merit 200 SL until the final sample period at 12 months (Xu et al. 2008). Trees treated with IMA-jet peaked at about $350 \mathrm{ppm}$ at 15 weeks post-treatment. Although the Merit 200 SL $(0.17 \mathrm{~g} / \mathrm{g} \mathrm{AI})$ treatment applied more active ingredient, lower residues were detected compared to the IMA-jet treatment. The Imicide and Pointer injections, along with the Merit 2 soil drenches, never produced concentrations different than zero during the 12-month study period. In another experiment, six $E$. sandwicensis were injected using Imicide and Sidewinder (as above) in a natural environment superficially similar to the site at Pu'u-o-kali (Waikoloa, Hawai'i island; $305 \mathrm{~mm}$ rainfall per year (12 in/yr) versus $375-500 \mathrm{~mm}$ per year (15-20 in/ yr) at Pu'u-o-kali). Mean tissue concentrations were determined three months post-injection and were too low to effectively limit EGW emergence (<2 ppm) (Xu et al. 2006; Xu et al. 2008). Soil type, rainfall and rooting habit may all be important for uptake and movement of imidacloprid and this is probably magnified by soil applications, which are exposed to an increased number of extrinsic variables. Systemic insecticide drenches appear to be more effective when used to treat containerized seedlings and saplings due to the confined root system as compared to trees in landscape settings (Xu et al. 2008). As per label instructions, Imicide and Pointer treatments were applied at much lower AI rates compared to either Merit 200 SL or IMA-Jet, which likely affected imidacloprid distribution to target tissues and concentration durability.

Emamectin benzoate has not been previously evaluated against EGW, but abamectin, which is chemically similar, has been assessed against galling wasps (including EGW) in a limited number of studies. In Kentucky, Eliason and Potter (2000) stem-injected Abacide ${ }^{\circledR}(1 \mathrm{~g} / 100 \mathrm{~g}$ abamectin; JJ Mauget Co.), at its label rate of $(0.004 \mathrm{~g} / \mathrm{ml} / \mathrm{cm} \mathrm{DBH})(0.01 \mathrm{~g} / \mathrm{ml} / \mathrm{in} \mathrm{DBH})$ against horned oak gall wasp, Callirhytis cornigera (Osten Sacken) (Hymenoptera: Cynipidae), in ornamental Pin oak, Quercus palustris Münchh. Their goal was to kill larvae within established galls and indeed they observed high levels of larval mortality in galls; however, the treatment had no effect on initiation of new stem galls. When the same rate and method were used to inject Abacide into E. sandwicensis and $E$. variegata in Hawai'i, little activity was observed against EGW (Xu et al. 2008). Causes of the observed variation in effectiveness among studies are uncertain, but could relate to toxicity differences among insect species, different formulation diffusion and distribution patterns among tree species, differences in tree physiology or different effects of heterogeneous environments.

The low emamectin benzoate residue concentrations and the lack of treatment durability in this study were surprising. Emamectin benzoate formulations have provided excellent residual activity against other insect pests when applied using similar dosages, e.g., eastern tent caterpillar, Malocosoma americanum (F.) (Potter et al. 2005), and southern pine engravers, Ips spp. (Grosman \& Upton 2006). Takai et al. (2003) injected a different emamectin benzoate formulation $(40 \mathrm{~g} / \mathrm{L}$; Shot Wan Liquid Formulation, formerly Novartis, now Syngenta, Japan; applied at $10 \mathrm{~g} \mathrm{AI} / \mathrm{m}^{3}$ of tree) into pines for nematode control and recovered residues of 0.08-2.09 and 0.15-2.14 ppm at 3 and 15 months respectively. After $35 \mathrm{~d}$ the study authors recovered residue levels of emamectin benzoate similar to those observed at three months by Takai et al. (2003); however, after 13 months this study's levels were not detectable while theirs were similar to their threemonth results. Whether this study's drop in emamectin benzoate concentrations at 13 months was related to leaf fall and refoliation, limited hydraulic conductance of active ingredient into the leaf tissue at application, or something else is not known. At the time of treatment, this study's trees had already experienced canopy injury and loss from EGW infestation. It seems plausible that this could alter uptake, movement and storage relationships more significantly with a large, water insoluble molecule like emamectin benzoate. Moisture availability may also have played a role in the translocation of emamectin benzoate in the dry, upland environment over time. As mentioned, the site at Pu'u-o-kali is hot and dry with only seasonal rainfall. Relative to emamectin benzoate, movement of imidacloprid may be less dependent upon hydraulic conductance due to its smaller molecular weight (about 25\%) and increased water solubility (about 21 times) (EXTOXNET, Extension Toxicology Network, Pesticide Information Profiles, IMIDACLOPRID, and Roberts and Hutson 1998).

The success of imidacloprid applications in this study and others suggests that this active ingredient is effective for maintaining Erythrina canopy and tree health for $>1$ year under severe pressure from EGW. In particular, IMA-jet injections with Arborjet Tree I.V. provided concentrations of imidacloprid sufficient to kill $80 \%$ of EGW in galls by $35 \mathrm{~d}$. Concentrations at 13 months, following a leaf senescence and refoliation event, were even 
higher (about 3x). Trees continue to be evaluated to document longer-term effects. Cost of IMA-jet per tree varies with dosage, but assuming a per liter cost of $\$ 350.00$ (Arborjet, January 2009), a tree with $\mathrm{DBH}<30 \mathrm{~cm}$ (12 in) would require IMA-jet costing \$14.00. Trees between 30 and $58 \mathrm{~cm}$ (12 to 23 in) DBH, typical of this study, would require $\$ 44.64$ of IMA-jet. In those situations where systemic applications are desired, imidacloprid appears to be the most effective AI choice of those yet tested, and IMA-jet a successful formulation/application/dosage choice. Parts of the world not yet infested with EGW can utilize this information as they prepare to combat EGW as it expands its range.

Acknowledgments. We thank Peter M. Wild, (Arborjet, Inc.), the U.S.D.A. Forest Service, R5 Forest Health Protection and the U.S.D.A. Forest Service, Southern Research Station for financial support. Keahi Bustamente, Andrea Buckman, Ka'ai Bustamente, Diana Crow, Ainoa Kai'aokamalie, Fernando Juan, Luke McLean, Alesa Kneubuhl, Jivan Osterneck, John Siasi, Briana Welker and Cassidy Ventura of the Haleakala Watershed Partnership for assistance in field work. Harry Zhong (Florida A \& M University) and John Mayer (HBEL, Inc.) developed analytical methods to determine emamectin benzoate residues. Joseph Fischer (SRS-RWU-4552) and Jerry Michael (SRS-RWU-4552, Retired) determined imidacloprid residues. Benjamen Parpart, James Parpart, Luke Reed and Steven Walters (SRS-RWU-4552) provided technical assistance with sample preparation. Special thanks to Charles Chimera (Hawaii Invasive Species Council) and Paul Krushelnycky (Pacific Island Ecosystems Research Center, U.S. Geological Survey) for initial review of the manuscript. Any use of trade, product, or firm names is for descriptive purposes only and does not imply endorsement by the United States Government.

\section{LITERATURE CITED}

Eliason, E.A., and D.A. Potter. 2000. Impact of whole-canopy and systemic insecticidal treatments on Callirhytis cornigera (Hymenoptera: Cynipidae) and associated parasitoids on pin oak. Journal of Economic Entomology 93:165-171.

Eliason, E.A. and D.A. Potter. 2001. Biology and Management of the Horned Oak Gall Wasp on Pin Oak. Journal of Arboriculture 27:92-101.

EXTOXNET. Extension Toxicology Network, Pesticide Information Profiles, IMIDACLOPRID. http://extoxnet.orst.edu/pips/imidaclo. htm (accessed 10/07/2008).

Grosman, D.M., and W.W. Upton. 2006. Efficacy of Systemic Insecticides for Protection of Loblolly Pine against Southern Pine Engraver Beetles (Coleoptera: Curculionidae: Scolytinae) and Wood Borers (Coleoptera: Cerambycidae). Journal of Economic Entomology 99 94-101.

Grosman, D.M., W.W. Upton, F.A. McCook, and R.F. Billings. 2002. Systemic insecticide injections for control of cone and seed insects in loblolly pine seed orchards-2 year results. Southern Journal of Applied Forestry 26:146-152.

Heu, R.A., D.M. Tsuda, W.T. Nagamine, J. A. Yalemar, and T. H. Suh. 2006. Erythrina gall wasp, Quadrastichus erythrinae Kim (Hymenoptera: Eulophidae). State of Hawai'i, Department of Agriculture, New Pest Advisory No. 05-03. 2pp.

Kim, IK, G. Delvare, and J. La Salle. 2004. A new species of Quadrastichus (Hymenoptera: Eulophidae): a gall-inducing pest on Erythrina (Fabaceae). Journal of Hymenoptera Research 13:243-249.

Lemmon, P.E. 1956. A spherical densiometer for estimating forest overstory density. Forest Science 2:314-320.
Li, H.M., H. Xiao, H. Peng, H.X. Han, and D.Y. Xue. 2006. Potential global range expansion of a new invasive species, the erythrina gall wasp, Quadrastichus erythrinae Kim (Insecta: Hymenoptera: Eulophidae). The Raffles Bulletin of Zoology 54:229-234.

Mathews, J.N.S., D.G. Altman, M.J. Campbell, and P. Royston. 1990. Analysis of serial measurements in medical research. British Medical Journal 300:230-235.

McWain, P., and G.F. Gregory. 1973. A benomyl-derived fungitoxicant for tree wilt disease control. USDA Forest Service Research Note NE-162. 3 pp.

Medeiros, A.C., L.L. Loope, and R.A. Holt. 1986. Status of the native flowering plant species on the south slope of Haleakala, East Maui. Cooperative National Park Studies Unit, Department of Botany, University of Hawai'i Tech Report 59. 230 pp.

Messing, R.H., S. Noser, and J. Hunkeler. 2009. Using host plant relationships to help determine origins of the invasive Erythrina gall wasp Quadrastichus erythrinae Kim (Hymenoptera: Eulophidae). Biological Invasions (in press, accepted Sept. 2008).

Neill, D.A. 1993. The genus Erythrina: taxonomy, distribution and ecological differentiation. pp. 15-27 in Westley, S. B. \& M. H. Powell (Eds.). Erythrina in the new and old worlds. Nitrogen fixing tree research reports special issue, Nitrogen Fixing Tree Association, Paia, HI.

Potter, D.A., L. Foss, R. E Baumier, and D. W. Held. 2005. Managing Eastern tent caterpillars Malacosoma americanum $(\mathrm{F})$ on horse farms to reduce risk of Mare reproductive Loss Syndrome. Pest Management Science 61(1):3-15.

Powell, M.H., and P.L. Nakao. 1992. Erythrina sandwicensis-Unique Hawai $i$ an NFT. NFT Highlights (Fact Sheet). NFTA 92-06. A quick guide to useful nitrogen fixing trees from around the world http:// www.winrock.org/fnrm/factnet/factpub/FACTSH/E_sandwicensis. html (accessed 9/05/2008).

Rauch, F.D., and D. Hensley. 1997. Wiliwili. Cooperative Extension Service, College of Tropical \& Human Resources, University of Hawaii at Manoa. OF-10.

Roberts, T.R., and D. H. Hutson. 1998. Metabolic Pathways of Agrochemicals: Herbicides and Plant Growth Regulators. Royal Society of Chemistry, Great Britain. pp. 87-94.

San Diego Zoo. 2008. Webpage. www.sandiegozoo.org/CF/plants/collectiondetail.cfm (accessed 5 October 2008).

Santiago, L.S., G. Goldstein, F.C. Meinzer, J.H. Fownes and D. Mueller-Dombois. 1999. Transpiration and forest structure in relation to water logging in a Hawaiian montane cloud forest. Tree Physiology 20:673-681

Smith, S.L., B.L. Strom, and J.R. Meeker. 2007. Early Detection Pest Risk Assessment Erythrina Gall Wasp. USFS. R5-FHP-2007-01. 4 pp.

Smith, S.L. and B.L. Strom. 2007. Identifying and Managing the Erythrina Gall Wasp, Early Pest Advisory. USDA Forest Service Forest Health Protection, R-5 \& Southern Research Station, Science Update SRS-012.

Takai, K., T. Suzuki and K. Kawazu. 2003. Distribution and persistence of Emamectin benzoate at efficacious concentrations in pine tissues after injection of a liquid formulation. Pest Management Science 60:42-48.

Wagner, W.L., D.R. Herbst, and S.H. Sohmer. 1990. Manual of the Flowering Plants of Hawai'i. B. P. Bishop Museum and University of Hawai'i Presses, Honolulu, HI.

Wiley, J., and P. Skelley. 2006. Erythrina Gall Wasp, Quadrastichus erythrinae Kim, in Florida. Pest Alert, Florida Department of Agriculture and Consumer Services, Division of Plant Industry. 
Xu, T., C.M. Jacobsen, I.K. Cho, A.H. Hara, and Q.X. Li. 2006. Application of an enzyme-linked immunosorbent assay for the analysis of imidacloprid in wiliwili tree, Erythrina sandwicensis O. Deg, for control of the wasp Quadrastichus erythrinae. Journal of Agriculture and Food Chemistry 54: 8444-8449.

Xu, T., C.M. Jacobsen, A.H. Hara, J. Li, and Q.X. Li. 2009. Efficacy of systemic insecticides on the gall wasp Quadrastichus erythrinae in wiliwili trees (Erythrina spp.). Pest Management Science, 65(2): 163-169.

Joseph J. Doccola (corresponding author)

Director of Research

Arborjet, Inc.

99 Blueberry Hill Road

Woburn, MA 01801, U.S.

joedoccola@arborjet.com

Sheri L. Smith

Regional Entomologist

R5 Forest Health Protection

U.S. Department of Agriculture

Forest Service

2550 Riverside Drive

Susanville, CA 96130, U.S.
Brian L. Strom

Research Entomologist

Southern Research Station

U.S. Department of Agriculture

Forest Service

2500 Shreveport Highway

Pineville, LA 71360, U.S.

Arthur C. Medeiros, Ph.D.

Research Biologist

Pacific Island Ecosystems Research Center

U.S. Geological Survey

Haleakala Field Station

P.O. Box 369

Makawao, (Maui) HI 96768, U.S.

Erica von Allmen

Botanist

Pacific Island Ecosystems Research Center

U.S. Geological Survey

Haleakala Field Station

P.O. Box 369

Makawao, (Maui) HI 96768, U.S. 
Résumé. La mouche à galle de l'Erythrina, dont son origine serait en Afrique, est une espèce décrite que récemment et s'avère maintenant un insecte invasif et sérieux chez l'Erythrina dans les zones tropicales et subtropicales. L'Erythrina est un arbre largement présent en aménagement paysager tout comme dans les écosystèmes menacés. La mouche à galle de l'Erythrina est un insecte très mobile et invasif qui cause des galles et provoque de sévères défoliations ainsi que la mortalité des arbres. La première détection de la mouche à galle de l'Erythrina aux ÉtatsUnis s'est faite à Oahu dans l'état de Hawaï en avril 2005. Le problème s'est rapidement disséminé dans les îles hawaïennes, tuant des Erythrina ornementaux et indigènes aussi jeunes que deux ans. Avec des risques endémiques sur les populations d'Erythrina et sur les autres espèces ornementales du même genre, le coût d'abattage des arbres morts s'est élevé aux dernières estimations à plus de $1000000 \$$. Parce que la mouche à galle de l'Erythrina est si petite et se dissémine si rapidement, les dommages à l'hôte sont généralement détectés avant que les mouches adultes ne soient observées, ce qui rend les traitements préventifs moins intéressants que ceux curatifs. Dans cet article, nous avons évalué deux insecticides injectés dans la tige, l'imidacloprid (IMA-jet $\left.{ }^{\circledR}\right)$ et le benzoate d'emamectine, injectés au moyen de l'équipement Arborjet Tree I.V.® en raison de sa capacité à couvrir la cime de E. sandwicensis (wiliwili) soumis à une exposition sévère par la mouche à galle de l'Erythrina. IMA-jet, appliqué à un taux de $0,16 \mathrm{~g} \mathrm{AI} / \mathrm{cm}$ de diamètre de souche, était le seul traitement efficace pour maintenir la cime en bonne condition chez le wiliwili. Le benzoate d'emamectine, appliqué à un taux de $\sim 0,1 \mathrm{~g}$ $\mathrm{AI} / \mathrm{cm}$ de diamètre à la souche, n'était pas efficace, et ce même s'il avait des effets intermédiaires entre les arbres traités à l'IMA-jet et ceux du groupe témoin. Les concentrations relativement élevées d'imidacloprid dans les feuilles et sa durabilité pour au moins 13 mois dans les wiliwili indigènes poussant dans les milieux naturels secs suggèrent que ces traitements contre la mouche à galle de l'Erythrina peuvent avoir un impact sur le recouvrement de la cime, et ce même dans un site sous-optimal ou des encore sur des arbres en mauvaise condition.

Zusammenfassung. Die Erythrina-Gallwespe (EGW), die in Afrika beheimatet ist, ist eine kürzliche beschriebe Art und heute eine ernste Bedrohung von Korallenbäumen in tropischen und subtropischen Gegenden. Korallenbäume sind bevorzugte gestalterische Bäume und auch Bestandteil eines nativen, heute bedrohten Ökosystems. Die EGW ist eine kleine, hoch mobile, hoch invasive Wespe, die durch Gallbildung ihren Wirt deformiert und Entlaubung sowie frühzeitiges Absterben bewirkt. Die erste Infektion von EGW in den Vereinigten Staaten war auf O’ahu, Hawaii im April 2005. Sie verbreitete sich schnell über die hawaiianischen Inseln und tötete innerhalb von zwei Jahren gepflanzte und wildwachsende Korallenbäume. Risikogruppen sind endemische Populationen von Korallenbäumen sowie gepflanzte Arten des gleichen Genus, wobei letztgenannte auf O'ahu mit Kosten von mehr als \$ 1.000000 schon abgestorben und entfernt worden sind. Weil die Wespe so klein ist und sich so schnell verbreitet, sind die Verletzungen an der Wirtspflanze eher entdeckt, als erwachsende Tiere entdeckt werden. Damit werden prophylaktische Behandlungen weiniger sinnvoll als therapeutische Behandlungen. In dieser Studie bewerteten wir zwei stamminjizierte Insektizide, Imidacloprid (IMA-jet ${ }^{\circledR}$ ) und Emamectin Benzoat von Arborjet Tree I.V.® equipment auf ihre Fähigkeit, das Kronensterben von E. sandwicensis (wiliwili)- Bäumen unter heftigem Befall durch EGW zu beeinflussen. (IMA-jet@) mit eine Gabe von $0,16 \mathrm{~g} \mathrm{AI} / \mathrm{cm}$ Basaldurchmesser) war die einzige effektive Behandlung von Wiliwili-Bäumen. Emamectin Benzoat, appliziert mit ungefähr 0,1 g AL/cm Basaldurchmesser war in dieser Applikation nicht effektiv, obwohl es zwischen dem Effekt von IMA-Jet-behandelten und unbehandelten Bäumen lag. Die relativ hohe Konzentration von Imidacloprid in den Blättern und die Verweildauer über mindestens 13 Monate in einheimischen Wiliwili-Bäumen auf natürlichen Trockenstandorten zeigen, dass die Behandlung gegen EGW auch unter suboptimalen Standort- und Pflanzenmaterialbedingungen eine Erholung der Kronen bewirken kann.

Resumen. La avispa de las agallas de la erytrina (EGW, por sus siglas en inglés), se cree nativa de África, es una especie recientemente descrita y ahora una plaga invasiva de Erytrina (árboles de colorín) en regiones tropicales y subtropicales. Los colorines son árboles ornamentales y de paisajes, como también árboles nativos de ecosistemas en peligro. El EGW es una diminuta, altamente móvil, altamente invasiva avispa que deforma (agalla) los hospederos causando defoliación severa y muerte del árbol. La primera detección de EGW en los Estados Unidos fue en O’ahu, Hawaii en Abril de 2005. Rápidamente se dispersó a través de la cadena de islas de Hawaii matando a los Erytrina ornamentales y nativos en poco menos de dos años. Las poblaciones endémicas están en riesgo como también las ornamentales en algunos géneros, el último del cual ha matado y removido de $\mathrm{O}^{\prime}$ ahu a un costo de $\$ 1,000,000$. Debido a que EGW son tan pequeñas y se dispersan tan rápidamente, el daño en el hospedero es usualmente detectado después de que las avispas adultas son observadas, haciendo los tratamientos profilácticos menos apropiados que los terapéuticos. En este estudio se evaluaron dos insecticidas inyectados al tronco, imidacloprid (IMA-jet $\left.{ }^{\circ}\right)$ y emamectin benzoato, a través del equipo Arborjet Tree I.V. ${ }^{\circledR}$, por su habilidad para afectar la copa de E. sandwicensis (wiliwili) bajo ataque severo de la avispa. IMAjet, aplicado a una dosis de $0.16 \mathrm{~g} \mathrm{AI} / \mathrm{cm}$ de diámetro basal $(0.4 \mathrm{~g} \mathrm{AI} / \mathrm{in}$. diam.), fue el único tratamiento efectivo para mantener la condición de la copa de árboles de wiliwili. Emamectin benzoato, aplicado a una dosis de $\sim 0.1 \mathrm{~g} \mathrm{AI} / \mathrm{cm}$ diámetro basal ( $\sim 0.25 \mathrm{~g} \mathrm{AI} / \mathrm{in}$. diam.), no fue efectivo en esta aplicación, aunque fue intermedio en efecto entre IMA-jet y árboles no tratados. Las concentraciones relativamente altas de imidacloprid en hojas, y su durabilidad por lo menos 13 meses en árboles nativos de áreas naturales y la resequedad del sitio, sugiere que las aplicaciones del tratamiento contra EGW pueden impactar la recuperación de la copa aun bajo condiciones de sitio y del árbol subóptimas. 